\title{
A Socio-Narrative Analysis of News Websites' Ideologies Reflected in the Use of Translated Excerpts from Arab Female Refugees' Testimonies
}

\author{
Sama Dawood Salman*
}

\section{Introduction}

The contemporary crisis of Arab refugees has been extensively covered by online press. Palestinian, Iraqi, Syrian and Libyan migrants have become a prime focus for many online news outlets. Amnesty International (AI) is one of the organizations that give undivided attention to refugee problems as part of its focus on putting an end to abuses of human rights. In 2016, the organization interviewed 40 Syrian and Iraqi female refugees to spotlight their suffering during their journey from their conflict-hit countries to Europe. Besides the danger of crossing the sea on unsafe and often fatal boats, these women face risks in the transit camps. They become subject to assaults and violence by human traffickers, stranger men on the same journey, and even security guards. Parts of the interviews with these refugees were quoted in an Arabic report released by the AI in an attempt to garner support from the international community, and urge governments to implement policies to protect this marginalized group. Once released, the report became first page news on various media websites. Some of the testimonies mentioned in the report were included in the posted articles, while others were excluded. This selective appropriation has helped agencies circulate the narrative that goes in line with their policies and interests. The present paper analyzes the way the translated statements of Arab female refugees are framed by a selected number of websites from a socionarrative perspective. The analysis is intended to show how translation can assist news agencies promote for their desired narratives.

The application of narrative theory in translation studies has been initiated by Baker in her book Translation and Conflict: A Narrative Account (2006). Since then, the approach has attracted the attention of many scholars of Translation Studies, including Harding (2012). Inspired by Baker's (2006) approach of how narrative theory can be used to analyze translations and believing that a sociological approach is complementary to the narrative construction and

\footnotetext{
* English Department, Faculty of Al-Alsun, Misr International University. Cairo Studies in English (2018): https://cse.journals.ekb.eg/
} 
interpretation, Harding $(2012,295)$ has developed the socio-narrative theory in translation. She proposes an intra-textual model to analyze translations in a way that links texts to the dimensions of time and place as well as to the issues of authority and power (303). Translation analysis, according to Harding's theory, goes beyond judging word choices and explores the relation between the translated text and its societal context.

This study applies Harding's socio-narrative theory (2012) to the analysis of how translated excerpts from one source text are incorporated into five news stories covering the same event. The analysis aims to reveal how women's voices are manipulated by the producers of the articles to promote for the narratives that serve the interests of the news agencies they represent.

\section{Research Questions and Hypothesis}

This study attempts to answer the following question: What does a socionarrative intra-textual analytical approach reveal about the way online press reconstruct the narratives of Iraqi and Syrian female refugees interviewed by Amnesty International? The study hypothesizes that narrators (writers/transeditors) of the selected online articles use the testimonies of the female refugees to serve their agencies' political purposes.

\section{Literature Review}

Ever since Baker (2006) initiated the analytical approach of looking at media translations as stories mediated by translators, researchers have made considerable headway on applying the narrative theory to translation analysis. Various studies have been conducted to demonstrate how translators use certain strategies to undermine or accentuate parts of the story they are translating. One source of examples that Baker has used to apply narrative theory is that of the Middle East Media Research Institute (MEMRI) where translators mange to frame events in a way that differs from the way they are narrated in the original text through features of temporality, relationality, causal employment and selective appropriation (Baker 2006, 51-70).

This review lists a number of relevant studies that tackle the issue of translation as re-narration in an English-Arabic context. Since the present study adopts a socio-narrative approach, the review covers a number of studies that have applied narratology and/or sociology to the analysis of translation in order to highlight the link between the three disciplines. To begin with, Bazzi (2009, 20) investigates the way Al-Manar TV, Hezbullah-affiliated channel, translated a number of news released by the French Press Agency. She illustrates how, for example, a term such as Palestinian suicide bombers is translated as martyrs to suit the ideology of the channel. Thawabteh $(2012,167)$ examines video clips of 
Palestinian people narrating the events that followed the Israeli occupation of Palestine in 1948. He himself translates the narrations into English to show how important it is for translators to give up neutrality when translating into a culture with a conflicting ideology. He emphasizes that translators need to assume their role as active participants in forming reality.

Baker $(2014,167)$ points out that every story undergoes a stage of selective appropriation when story narrators filter out details to promote the ideology of the institutions they belong to. Along the same line, Jahanshahi and Pedram $(2015,881)$ analyze the way a given event is covered by four different news agencies: Al-Jazeera, BBC, PressTV and IRIB News. They come to the conclusion that each of the selected news agencies narrates the event in a way that reflects its editorial policy. By contrast, Jaber $(2016,79)$ examines over three hundred articles published by The Guardian and The New York Times on the humanitarian disaster in Syria within the framework of Baker's approach. The analysis focuses on the translation of embedded quotations by Syrian eyewitnesses. His findings show that the two newspapers are committed to translation ethics and represented the narratives of the eye-witnesses objectively and fairly.

Moreover, some relatively recent studies look at translation as both renarration and a social system that shapes reality. Such attempts draw heavily on the works of Sociology theorists such as Latour (2005) and Luhmann's (2006). Inghilleri $(2011,282)$ points out that the main contribution of Sociology to Translation Studies is that it encourages looking at translators as visible actors whose linguistic choices result from their interaction with the social system. Qun-xing $(2016,148)$ maintains that the importance of socio-narrative approach to translation is that it shows the key role that translators play in the society through the narratives their translations help to circulate.

\section{Theoretical Underpinnings}

\section{Harding's Theory: The Interplay between Sociology, Narratology, and} Translation

Harding's (2012) work is largely drawn from the approach suggested by Baker (2006) of how narrative theory can be applied to Translation Studies. She, however, has contributed to that approach to come up with what she calls "socionarrative theory". This section discusses four aspects of Baker's (2006) approach that have been developed by Harding (2012) to form the basis of her suggested intra-textual model of analyzing translation.

The first contribution Harding has made is related to narratives typology. Baker (2006, 28-39) differentiates between four types of narratives. The first 
type is called ontological or personal narratives, which refer to our own stories about our position in the world. The second type is termed public narratives, which are defined as stories that are circulated by institutions rather than individuals. Disciplinary narratives are the stories that researchers elaborate about their fields of specialty; and, finally, meta-narratives are these stories we tell about our role in history and the age we are living in.

Believing that there is a need for distinguishing between personal narratives and the other three types, Harding (2012) suggests a two-category narrative typology: personal narratives and shared or collective narratives. Similar to the definition suggested by Baker (2006), Harding defines personal narratives as stories that people build about themselves. Shared or collective narratives, on the other hand, are stories that are created "collectively by the collective" either through agreement or forcibly. This type of collective narratives includes Baker's three types: public, disciplinary, and meta-narratives. Moreover, Harding suggests calling public narratives "societal" since the narratives that are circulated among members of a given institution may or may not be communicated to the public. She also prefers calling disciplinary narratives "theoretical" as this new name refers more broadly to the abstract terms used to describe events, not only narratives that are common between people of the same profession. Harding adds a fourth type; namely, "local narratives" which are stories related to certain incidents that happen in a certain location within a certain time framework. These four types of shared or collective narratives are placed on a particular-general continuum to reflect the interrelation and interaction between them and the clear-cut difference between local and metanarratives, which are at the opposite ends of the continuum (Harding 2012, 292294).

The second contribution Harding makes to Baker's approach is linking it with a sociological perspective. She backs her argument through discussing the concepts of text, fabula and story, to show the relation between the two approaches. Harding $(2012,296)$ adopts Bal's $(2009,57)$ definitions that view text as a set of linguistic symbols termed "primary narrative"; fabula as a series of events that affect or are affected by players at a certain time and place; and story as the way these events are related to each other temporally and spatially. Harding $(2012,132)$ maintains that to structure a news story, the narrator (a writer/trans-editor) makes use of two main elements. The first one is "retroversions" which refer to insertions of events from other narrators into the primary narrative text. These fall into two types: external retroversions that occur when a narrator intentionally makes reference to events that happened before the primary narrative, and internal retroversions which are related to the case when the narrator mentions events that happened within the time frame of the primary 
narrative. The other element that narrators may resort to in order to create their stories is the "actor". That is, the narrator may highlight the role of given characters and picture them in a certain way such as heroes or victims. Another contribution made by Harding $(2012,302)$ to the narrative approach is the clear distinction she draws between narrators and temporary narrators who assume the role of narrators for a while. Temporary narrators include authorities, experts, and eye-witnesses who are selected by narrators to build the primary narrative text.

These concepts and terms are discussed by Harding to pave the way for her intra-textual analysis model. The model's main advantage, according to her, is that it does not deal with the primary narrative text as a whole, but rather as a structure that could be broken into different types of texts. Every prime narrative text consists of non-narrative material (e.g. statements, quotations, testimonies), and narrative material (e.g. facts, figures, events) that could be either taking place at the same time span of the primary narrative text (synchronal) or happening before it (anachronic). Harding subdivides the synchronal material according to place. Thus, it could be related to events either occurring at the location of the primary narrative text or taking place close to it (2012,300-301). It is to be noted that narrative material differs from non-narrative one in that the former denotes a series of events arranged by the text producer to suggest a certain frame to the events, while the latter refers to any kind of statements made by someone other than the text producer such as eye-witnesses or authorities, and which are carefully selected to further enhance the intended frame.

Harding uses her intra-textual model to explore the way a hostage-taking incident that took place in Beslan in 2004 was reported by Russian news articles and compare them with their English translations. The findings of her study show that news agencies have managed to construct different narratives through selecting/deselecting narratives of certain eye-witnesses, experts and government officials. Harding concludes her argument by highlighting how the application of socio-narrative theory to translation and text analysis can explain the way narrators "re-narrate their temporary narrators" (2012, 302-303).

This study applies the socio-narrative approach, as suggested by Harding, to explore the way the more powerful narrators (i.e. writers and news outlets) marginalize or bring to the fore the narration of the temporary narrators (the female refugees and officials in this study) to construct the primary narrative texts. 


\section{Methodology}

This paper follows a qualitative analysis research design to explore how translated excerpts are woven together with facts, figures, information and events to serve the ideology of the news institutions. The data consists of English online articles with embedded statements and testimonies translated from an Arabic report issued by Amnesty International (AI) on the difficulties that Iraqi and Syrian female refugees encounter in the transit camps. The report was released on 18 January 2016 and was translated into English, then circulated among many online news agencies and websites. Five articles published by different media outlets are selected to be the data of this study. These include news stories posted on the websites of the French News Agency (AFP), Associated Press (AP), Time, Washington Post, and PressTV from 18-19 January 2016. These websites are chosen for two main reasons: 1) they are popular and accessed daily by a wide range of global audiences; and 2) they have different agendas that influence the manner they cover news.

Following the data collection, an intra-textual analysis is conducted, adopting Harding's Socio-narrative Theory (2012). The analysis aims to show how translated excerpts from the report are used by these news channels to circulate their "version" of reality. It is to be mentioned that although the narrative parts usually reflect ideological aspects of translation, this study focuses mainly on analyzing the non-narrative parts (translated statements and testimonies) in order to show how translated excerpts can be used by writers and trans-editors to further establish the ideologies of their institutions.

Before moving to the analysis of the five selected English online news articles, it is useful to present some information about the news organizations that posted these articles. Such information can give hints of their biases in covering the news, and unfold their hidden agendas that dictate the way they select the translated excerpts. Both The $A F P$ and $A P$ are left-center biased that use relatively moderate language in covering political events. However, the former covers affairs from the European point of view since it is headquartered in Paris, while the coverage of the New York-based $A P$ goes in line with the policies and views common in the United States. The Time news magazine has always shown sympathy with refugees, and selected Chancellor Merkel of Germany the person of the year in 2015 for her effort to alleviate their sufferance. By contrast, the Washington Post is known for an anti-Merkel reputation though the newspaper itself has published several articles calling for helping refugees. PressTV is an Iranian state-owned news network that broadcasts news in both English and French. The way it covers the Middle East affairs counters the coverage and ideologies of the western media. 


\section{Data Analysis and Discussion}

Each of the selected articles is a primary narrative text that includes narrative and non-narrative parts to different degrees. The original Arabic text begins with a brief background and blames world's governments for not providing enough protection to female migrants. It cites the official statements of Tirana Hassan, Amnesty International's Crisis Response Director, who highlights the urgent need for immediate action to safeguard these women. The article then moves to the testimonies of 7 out of the 40 women that were interviewed by the (AI). One of these testimonies is indirectly quoted, while all the other ones are in the form of direct. The problems that these women and girls reported include: mixed sleeping areas and toilets, sexual harassment, and police violence. The narrative part of the article is synchronal (i.e. taking place at the time of the primary narrative text); however, few non-narrative parts are anachronic (i.e. taking place before the primary narrative text). Tirana Hassan's statements are mostly about the present crisis, but she also makes reference to the "horrors of war" that these females have experienced back there in their countries. The same could be said about the site of events, which is mainly in the transit camps in Europe with a little reference to the points the migrants passed by to reach their destination. Moreover, the article includes a number of temporary narrators. The role of narrating is passed from the article producer to an official (Tirana Hassan), and, then, to the eye-witnesses. It is to be mentioned that the testimonies of the female refugees in the selected text are classified as personal narratives that are meant to be public ones. These women are not merely sharing their personal experience, but rather they are calling for an action through circulating a public narrative.

The articles of $A F P$ and $A P$ directly quote translated parts of the Arabic article, and include very brief narrative texts where the article producer provides an introduction about the report. The largest part of the two articles is nonnarrative. The $A F P$ article producer quotes and summarizes some parts of the Arabic report, and includes two statements by Tirana Hassan, calling for immediate action to protect the migrants and preserve their dignity. Out of the seven eye-witnesses whose testimonies are included in the Arabic text, only one eye-witness is selected (a 22-year-old Iraqi woman talking about a sexual harassment incident in Germany). The same could be said about the $A P$ article except that the text producer replaces the statement of Tirana Hassan with that of Jenny Becker, Protection Coordinator at the International Rescue Committee. In her statement, Jenny criticizes governments' late response to the crisis of female refugees. 
The Iranian PressTV is a third narrator (news agency) that covered the report news. In addition to the story of the 22-year-old Iraqi woman and the statement of Jenny Becker, the article producer includes a two-sentence anachronic narrative (external retroversion) which takes the reader back to the real reason why these women had to leave their countries (i.e. the policies of America and European powers). Moreover, PressTV article includes some figures released by the International Organization for Migration, highlighting the dangers that migrants face during their journey to Europe.

The Time magazine article discusses the hazards that female refugees all over the world, not only Syrian and Iraqi ones, face. It begins with a relatively long introduction where the writer lists the challenges that these women encounter during migration. It then focuses on Amnesty report, quoting directly the testimony of a 20-year-old woman who talks about kinds of sexual harassment that deprive women of sleeping. The article indirectly quotes Hala, a 23-yearold migrant, describing how she and her friend were tempted by smugglers in Turkey. The writer ends her text calling on international community to exert further efforts to support female refugees. The narrative part of the article is both anachronic taking the reader five years ago when the refugee crisis has started, and synchronal focusing on the time of the report.

The last article to be analyzed here according to the model is the one posted on the website of the Washington Post. As is the case with the previouslydiscussed articles, the Washington Post story includes narrative and nonnarrative parts. The non-narrative material contains a report that was issued by United Nations High Commissioner for Refugees (UNHCR), reports by German police, a statement by Tirana Hassan, and three testimonies of those who were interviewed in the Arabic text. One of the women's testimonies is about sexual harassment, while the other two are about police brutality. Moving to the narrative part in this article, there are two examples of external retroversions: the text producer refers to the UNHCR report that was released earlier, and a sexual assault incident that took place on New Year's Eve (approximately two weeks before Amnesty report was released). Furthermore, while the article talks about assaults across Europe in general, a number of incidents that took place specifically in Germany are mentioned to situate that country at the core of the narrative. This could be an attempt by the news institution to criticize the decision made by German Chancellor Angela Merkel in 2015 to welcome Arab refugees. It seems that the article producer is trying to promote a counternarrative that defies framing Merkel as a heroine.

The analysis of the selected articles reveals that the text producers of each of them managed to re-narrate the Amnesty International report in a manner that reflects the ideology of their news agencies. This is achieved through the 
following: 1) selecting/deselecting the accounts of the eye-witnesses, 2) inserting external retroversions, and 3) portraying the actors in a certain frame that matches the intended narrative. Four of the five articles cite the account of a 22-year-old Iraqi woman reporting an incident of sexual harassment committed by a German guard. Selecting this particular story reinforces the image of these women migrants as victims, threatened by the men who are supposed to protect them. Time's article, on the other hand, marginalizes this incident through excluding it while including two accounts that are overlooked by the other four articles. These are the accounts of two Syrian young women complaining of the repeated incidents of sexual harassment by refugee men and smugglers. This selection/deselection technique helped the Time's text producer strengthen her argument that the world leaders need to provide security measures to protect these women. This shows how storytelling, as Baker $(2006,167)$ mentions, involves a process of selective appropriation that echoes the position of the news agency.

Furthermore, three of the selected English texts include external retroversions. The Time article starts with reference to the five-year-old refugee crisis. However, the writer does not blame the United States of America for causing this crisis. On the contrary, it pictures this superpower as the defender of those women. The PressTV article, by contrast, states that many blame major European powers for this ordeal in an attempt to take the reader back to the reasons behind the current situation. The external retroversion shifts the emphasis from the dangers faced by female refugees to the refugees' crisis as a whole. This proves the point stressed by Harding $(2012,297)$ that external retroversions can greatly affect the way narratives are constructed.

As for the actor(s) presented in each of the selected articles, two main characters are presented in the article besides the interviewed refugee women. Tirana Hassan, Amnesty International's Crisis Response Director, is quoted in the AFP and Washington Post articles, while Jenny Becker, Protection Coordinator, is quoted in the AP and PressTV. Hassan is depicted as a defender of the rights of these women. Her statements describing the miseries of these women reinforce their image as victims. Becker criticizes the indifferent governments and international community; she is sketched as a preacher or moralizer. This supports Baker's $(2004,167)$ opinion that the way characters are portrayed by text producers contributes to the narrative they try to circulate. It also agrees with Harding's $(2012,302)$ findings that news agencies can build their narratives through their choice of officials and authorities.

Each of the articles narrates the report from a different perspective. The $A F P$ calls for taking measures to preserve the dignity of the refugees. Having its 
headquarters in Europe, the $A F P$ frames the refugees' crisis as a problem creeping up on Europe, and suggests that it should be addressed by European governments. It narrates the female migrants' sufferings as a social issue that is rising to the surface. The $A P$ article criticizes the governments' apathy towards the refugee crisis. PressTV accuses America and the European powers of being the reason why these women had to leave their own countries. The Time magazine presents the refugee crisis as an issue of global concern as it spreads all over the world. By so doing, the text producer keeps away from the minds that this is the fault of America. The article producer also silences other voices through not citing any of the officials whose statements are quoted in the other articles. The Washington Post article promotes the idea of a hidden narrative that Germany is not a safe haven for refugees. It does not focus only on sexual harassment, but includes various kinds of incidents that have happened specifically in Germany. Unlike the other articles, the Washington Post story does not call on the international community to take action, but it implies that this is the responsibility of America as it is the defender of the whole world.

The findings of the study agree with those of Jahanshahi and Pedram (2015, 881) who hold the view that text producers may change the original narrative to match the policies of the institutions they belong to. They also support Qunxing's $(2016,148)$ belief that socio-narrative theory is important in Translation Studies as it highlights the active role that translation play in circulating narratives.

\section{Conclusion}

The present study concludes that a socio-narrative intra-textual analysis is significant to view a text not as a collection of linguistic symbols, but as a reflection of the world we, and of course text producers, interact with. The analysis shows how translated statements of female eye-witnesses and officials are selectively appropriated and manipulated to construct different narratives by online news writers. The text producers/trans-editors have made the best use of certain tools to steer their stories. These include selective appropriation, external retroversions, and actors. Inclusions and/or omissions of certain details have helped news narrators undermine the original narrative and shift the emphasis from one aspect to another. The findings of the study highlight the dynamic role that translation plays in shaping people's understanding of events through reconstructing and circulating narratives that carry the policies of media institutions. They also emphasize the role played by translation in giving voice to marginalized people. The translation of the women refugees' testimonies has turned them from invisible, victimized females into a loud, powerful voice. It is to be noted that this study does not judge neither text producers nor media 
institutions. The examples show that some agencies cover news in a way that shows their support to a certain cause. The results reveal that the non-narrative parts of news articles are as significant as the narrative parts. Hence, although quotations and statements are a fixed kind of material, they can be used as a tool to further emphasize the narrative that the text producer tries to promote.

One thing that needs consideration here, but could not be covered by the study due to lack of enough information is the gender of the text producer. Being a woman might be one of the reasons why the Time article producer shows more sympathy towards the women refugees than that shown by the writers of the other articles. This was hard to discuss in the study because not all the selected articles mention the name of their producers. Moreover, deeper insights into the way agencies use intra-textual elements to reconstruct narratives could have been gained if the interviews with these women were televised. In such a case, lighting, camera movements, shots, and angels could play a major role in the representation of these women and their narratives. The gender of the footage director/editor could also be covered in such analysis. This may encourage future researchers to link socio-narrative theory, media studies, and feminist translation approaches.

\section{Works Cited}

Agence France-Presse. 2016. "Female refugees face abuse on migrant trail in Europe: Amnesty London." 18 January 2016. https://www.afp.com/en/news/female-refugees-face-abuse-migrant-traileurope-amnesty-143616919.html.

Associated Press. 2016. "Violence stalking Europe-bound female migrants at every step, Amnesty says." 18 January 2016. https://www.ap.org/en/news/2016/01/18/world/social-issuesworld/violence-stalking-europe-bound-female-migrants-every-stepamnesty-says/.

Baker, Mona. 2014. "Translation as Re-narration." In Translation: A Multidisciplinary Approach, edited by Juliane House, 158-177. New York: Palgrave Macmillan.

-----. 2006. Translation and Conflict: A Narrative Account. London/New York: Routledge.

Bal, Mieke. 2009. Narratology: An Introduction to the Theory of Narrative. Toronto: University of Toronto Press.

Bazzi, Samia. 2009. Arab News and Conflict: A Multidisciplinary Discourse Study. Amsterdam/ Philadelphia: John Benjamins. 
Harding, Sue. 2012. "How Do I Apply Narrative Theory: 'Socio- Narrative Theory in Translation Studies."' Target 24, no. 2: 286-309.

Huang, Margaret. 2016. "We're Failing to Provide Protection to Female Refugees: They Deserve Our Support," Time, 19 January 2016. http://amp.timeinc.net/time/4499456/unga-female-refugees/

Inghilleri, Moira. 2011. "Sociological Approaches." In Routledge Encyclopedia of Translation Studies, edited by Mona Baker and Gabriela Saldanha, 279282. London and New York: Routledge.

Jaber, Fadi. 2016. "Representing, Narrating, and Translating the Syrian Humanitarian Disaster in The Guardian and The New York Times." Global Media Journal 9, no. 2 : http://www.gmj.uottawa.ca/1602/v9i2_jaber.pdf.

Jahanshahi, Maryam, and Parvaneh Pedram. 2015. "The Role of Translators \& Interpreters in Reporting the News; Comparing of News Based on Baker's Model." Cumhuriyet University Faculty of Science Journal 36, no. 6. http://dergi.cumhuriyet.edu.tr/cumuscij/article/view/5000139008.

Latour, Bruno. 2005. Reassembling the Social: An Introduction to ActorNetwork-Theory. New York: Oxford University Press.

Luhmann, Niklas. 2006. "System as Difference." Sage 13, no. 1 (January): $37-$ 57. http://journals.sagepub.com/doi/pdf/10.1177/1350508406059638

Noack, Rick. 2016. "These are the Forgotten Sexual Assault Victims in Europe," Washington Post, January 18, 2016.

http://www.washingtonpost.com/news/worldviews/wp/2016/01/18/these-arethe-forgotten-sexual-assault-victims-in-europe $/$ ?utm_term $=. e 8 c a 5 a 6 e 18 \mathrm{cb}$.

PressTv. 2016. "Female refugees heading to Europe face sexual violence: Amnesty." $18 \quad$ January 2016. http://www.presstv.com/Detail/2016/01/18/446225/Female-refugeesEurope-sexual-harassment-Amnesty-International.

Qun-xing, Zhang. 2016. "Translator's Voice in Translated Texts." Journal of Literature and Art Studies 6, no. 2 (February): 178-185. http://doi.org/ 10.17265/2159-5836/2016.02.007.

Thawabteh, Mohammad. 2012. "Translation and Conflict: Two Narratives of the Same Coin." The Southeast Asian Journal of English Language Studies 18, no. 4: 215-226.

https://www.researchgate.net/publication/257339069_Translation_and_Con flict_Two_Narratives_of_the_Same_Coin.

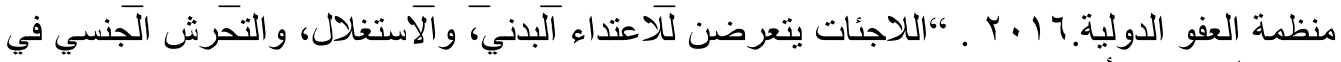

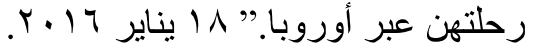

https://www.amnesty.org/ar/latest/news/2016/01/female-refugees-facephysical-assault. 